\title{
Determination of the Jouamaa groundwater quality using Physico-chemical water analysis and Geographic Information System
}

\author{
El Mustapha Azzirgue ${ }^{1 *}$, Farida Salmoun ${ }^{1}$, El Khalil Cherif ${ }^{2}$, and Nezha Mejjad ${ }^{3,4}$ \\ ${ }^{1}$ Laboratory of Chemistry, Unit (LPMSE) / University of Abdelmalek Essaadi. Tangier - Morocco \\ ${ }^{2}$ Institute for Systems and Robotics, Instituto Superior Técnico, University of Lisbon, Lisbon - Portugal \\ ${ }^{3}$ Department of Geology, LGAGE, Faculty of Sciences Ben M'Sik, Hassan II University, Casablanca - Morocco \\ ${ }^{4}$ Department of Geology Laboratory of GMSSURAC 45, Faculty of Sciences, Chouaib Doukkali University, El Jadida 24000, \\ Morocco
}

\begin{abstract}
The present study seeks to determine the water quality of wells located in the Jouamaa Hakama commune (Northern Morocco). In this order, nine water samples were collected from wells used by local residents during two sampling campaigns in December 2016 and June 2017. The samples collection was followed by the laboratory analysis for measuring the water Physico-chemical characteristics including $\mathrm{pH}$, temperature $\left(\mathrm{T}^{\circ}\right)$, Conductivity (Cond), Chemical Oxygen Demand (COD), Biochemical Oxygen Demand (BOD5), Dissolved Oxygen (DO), Suspended Matter (SM), Turbidity, Nitrite, Nitrate, Ammonium and Phosphate. Also, spatial data analysis has been done using Geographic Information System (GIS) by ArcGis software to show a statics map with significant water quality information for the studied wells. The spatial analysis showed higher concentrations exceed the Moroccan groundwater quality values in P6 and P8 for the EC in 2016 and 2017. Similarly, for the turbidity, higher values recorded in P8, while the DO concentration was significant in P6, P8 and P9, other sampling points indicate values close and inferior to water quality standards. P3, P4, and P8 showed higher Ammonium, Nitrite and phosphate values during the summer period of 2017. The analysis results shed light on contamination factors: domestic activities and agricultural activities in urban zones (Hakama and Jouamaa). However, the use of these waters could pose a risk to the health of human and animals. Similarly, The GIS is a practical, innovative and effective tool for the Jouamaa groundwater quality diagnostic and could help decision-makers establish solutions.
\end{abstract}

\section{INTRODUCTION}

Groundwater is a vital source commonly used for irrigation, industrial water supply and drinking water in urban and rural areas. About $50 \%$ of drinking water and $43 \%$ of the water used in agriculture worldwide come from groundwater [1]. However, the increasing demand for clean water poses a risk to this resource precisely in semi-arid and arid areas [2], where it faces various issues associated with pollution and water quality deterioration [3]. Monitoring and assessing the water quality is crucial as it provides valuable information and data for water management planning associated explicitly with drinking water quality.

Different type of materials was found in groundwater and identified as contaminants including pesticides (plant protection products) [4], petroleum hydrocarbons [5], toxic substances (e.g. Heavy metals) [6], radioactive solutions [7], and pathogens [8]. Groundwater and well water cannot be decoupled even if their vulnerability to contamination is different. Wells water can be contaminated by naturally occurring sources or anthropogenic activities. According to US Environmental Protection Agency (EPA) [9], private wells can receive contaminants from human sewage and animal waste (bacteria, virus and parasites), agriculture activities (nitrate and nitrites), and industrial activities (heavy metals, radionuclides and fluoride).

Wells water vulnerability to contaminants is governed by contaminant input, persistence and mobility, and technical aspects such as location, design, operation, and construction [10]. Thus, improperly constructed and located wells could be a source of groundwater contamination [11].

Water resources in Morocco suffer from drought and pollution related to human activities such as industrial and agricultural activities [12-14]. This continuous increase of human activities leads to groundwater quality deterioration [3], while about $40 \%$ of used water for irrigation in Morocco derives from groundwater, contributing approximatively to $75 \%$ of vegetable crops

\footnotetext{
*Corresponding author: elmustapha.azzirgue@gmail.com
} 
and orchard of the country's export. In the TetouanTangier region, groundwater is mainly used to source domestic and agricultural activities, drinking, and animal drinking [15].

Jouamaa located in the north of Morocco near Tangier, precisely in the downstream part of the wastewater discharge of WWTP Chrafate. This WWTP treats wastewater received from the Tanger Automotive City (TAC) industrial zone. The discharges from the STEP are evacuated in Oued Ouljat Echatt [16].

Thus, the present paper aims at determining the wells water quality in the Jouamaa Hakama commune by analyzing the water Physico-chemical parameters and using GIS as a tool, allowing more understanding of the quality indicators spatialization reveals interactions between the various phenomena acting on the functions of this study area.

\section{PRESENTATION OF THE STUDY AREA}

The study area, about $17 \mathrm{~km}$ far from Tangier, is located downstream of the wastewater discharges treated by the STEP Chrafate, which treats the wastewater from the Tanger Automotive City (TAC) industrial zone. The discharges from the STEP are evacuated in Oued Ouljat Echatt. The wells are distributed along the wadi between the Lambert coordinates: $X=471061, Y=559489$ and $X=475800, Y=563445$ (Fig. 1). The altitudes vary from $37 \mathrm{~m}$ at the Ibn Batouta dam to $96 \mathrm{~m}$ at the level of the Chrafate WWTP. [16] The study area includes the Ouljat Echatt River as well as several small temporary or torrential tributaries. All the wells are used by the commune residents and the Ibn Batouta dam. From the geology side, the study area is part of the Rif domain of northern Morocco, which containing the flysch aquifers with a few units from the outer Rif [17] [Michard A, (1976)]. In this sector, the Tangier unit represents the outer Rif, which constitutes the substratum of the flysch aquifers. The study zone includes outcrops belonging to the flysch formations, large outcrops of the Tangier predominantly clay unit forming part of the outer Rif, and a few Quaternary formations, especially alluvial. [18] (Yassir T. et al., 2016). The study region is characterized by two seasons, one dry and hot and the second, wet and cold, longer than the first [19] [El Gharbaoui A, (1981)]. The climate is the sub-humid Mediterranean with a humid and mild winter and a dry and hot summer lasting five months, from May to September [20] (KARROUK, 1990). The area takes advantage of the combined influence of two maritime facades (the Mediterranean and the Atlantic) and records an average rainfall of around $765 \mathrm{~mm}$ per year [21] (ACHAB, 2011). [22] (Nabil RIFA, 2013).

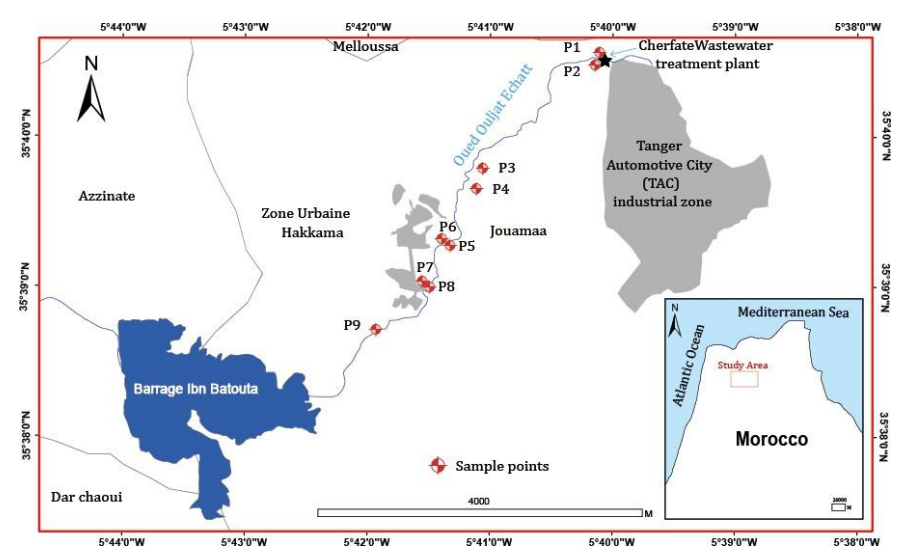

Fig.1. The geographical location of the study area and sampling locations.

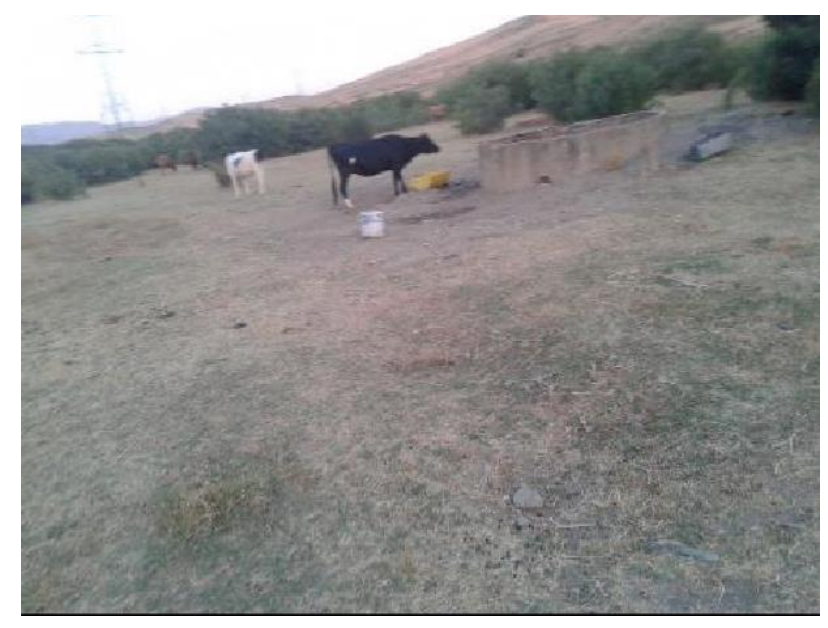

Fig. 2. The use of well water for animal watering and daily needs.

\section{MATERIALS AND METHODS}

\subsection{Sampling and sampling sites}

Nine wells used by residents for their daily water needs (Figure 2) situated along the Ouljat Echatt wadi were chosen and positioned using GPS to collect and analyze the quality of their waters. (Figure 3). The groundwater samples were collected during two sampling campaigns in December 2016 and June 2017. The sampling was carried out by using polyethene bottles. The containers were priory washed by distilled water and dried to avoid the contamination of the sample, and then each bottle was rinsed with the water to be analyzed before being used [23]; they were numbered before sampling [24]. 


\subsection{Physico-chemical parameters analyzed}

In order to study the wells water quality, the samples were analyzed to determine the Physico-chemical parameters of each sample, including $\mathrm{pH}, \mathrm{T}^{\circ}, \mathrm{DO}$, COD, BOD5, SM, Turbidity, Nitrite, Nitrate, Ammonium and Phosphate. The analysis was performed according to Rodier's water quality assessment techniques and the recommendations of the World Health Organization (WHO) and Moroccan standard.

The $\mathrm{pH}, \mathrm{T}^{\circ}$ and electrical conductivity analysis were performed in situ just after retrieving the samples to avoid any contamination or change of the parameters of the sample. Other chemical parameters were determined in the Laboratory of Chemistry Unit (LPMSE) laboratory at the University of Abdelmalek Essaadi Tangier, Morocco. Table 1 presents all the parameters measured for each sample and the used analytical methods, standards, and parameters.

Table 1: Different measured parameters and used methods in the present study.

\begin{tabular}{|l|l|l|c|l|}
\hline Parameters & Analytical method & Unit & $\begin{array}{c}\text { Maximum } \\
\text { Allowable } \\
\text { Values }\end{array}$ & References \\
\hline $\mathrm{pH}$, & pH meter in situ & --- & $6,5<\mathrm{pH}<8,5$ & NM 03.7.009, \\
$\mathrm{T}^{\circ}$ & Thermometer & ${ }^{\circ} \mathrm{C}$ & $\mathrm{T}^{\circ}<25$ & \\
Conductivity & Conductimeter & $\mu \mathrm{S} / \mathrm{cm}$ & 2700 & NM 03.7.011, \\
BOD5 & BOD5 meter & $\mathrm{mg} / 1$ & $<30$ & NF T90-103 \\
COD & COD meter & $\mathrm{mg} / 1$ & $30-50$ & NF T90-101 \\
DO & Oximeter & $\mathrm{mg} / 1$ & $5<\mathrm{O}_{2}<8$ & Rodier 2009 \\
$\mathrm{SM}$ & Gravimetric & $\mathrm{mg} / 1$ & $50-200$ & NF T90-105-2 \\
Turbidity & Turbidimetry & $\mathrm{NFU}$ & 5 & NF T90-033 \\
Nitrite & Spectrophotometry & $\mathrm{mg} / 1$ & 0,5 & NF T 90-040 \\
Nitrate & Spectrophotometry & $\mathrm{mg} / 1$ & 0,5 & Rodier 2009 \\
Ammonium & Spectrophotometry & $\mathrm{mg} / 1$ & 50 & Rodier 2009 \\
Phosphate & Spectrophotometry & $\mathrm{mg} / \mathrm{l}$ & $0,2-0,5$ & Rodier 2009 \\
& & & & \\
\hline
\end{tabular}

\subsection{Data spatialization (GIS)}

The Physico-chemical characteristics of the water wells characterization obtained were integrated into GIS using ArcMap 10.2.2 for mapping the distribution of the analyzed parameters to do a spatial treatment and show the non-conform wells sites according to the national norms.

\section{RESULTS}

The exploitation of the results is based on comparing our analysis data carried out on well water samples with Moroccan and WHO standards. The Physico-chemical quality of the water provides information on the location and assessment of a level of pollution based on a set of parameters based on reference values [42] [28].

\subsection{Physical parameters}

\subsection{1 $\mathrm{pH}, \mathrm{T}^{\circ}$, Cond}

The $\mathrm{pH}$ values of the waters of the wells analyzed appear slightly acidic in 3 wells and slightly basic in the other wells during the summer period, and basic for all the wells during the winter. The obtained values fluctuate between 6.82 and 8.05 . Therefore, our results situated in the range of water intended for human consumption, 6.5 $<\mathrm{pH}<8.5$ (WHO). Similar values were found in a study carried out in Tangier-Tetouan in 2014 by [30].

The temperature $\left(\mathrm{T}^{\circ}\right)$ of water plays an important role in controlling the chemical composition of groundwater. [41]. In our study area, the results obtained showed that the temperatures do not exhibit significant variations, with a minimum of $18.80^{\circ} \mathrm{C}$ and a maximum of $20.9^{\circ}$ $\mathrm{C}$. These values situated between the range of Moroccan standard for drinking water $\left(5^{\circ} \mathrm{C}<\mathrm{T}<25^{\circ} \mathrm{C}\right)$. The same result was found by M.L. Belghiti et al. (2013) [25] in the Meknes region with a water $\mathrm{T}^{\circ}$ of a minimum of $20^{\circ} \mathrm{C}$ (well P1, P3, and P4) and a maximum of $21.04{ }^{\circ} \mathrm{C}$ (well P7 and P11). Similary, M. Ben Abbou et al. (2013) [40] found in the Taza region, average values of $\mathrm{T}^{\circ}$ of $20.9^{\circ}$ C. While I. Nechad et al. (2014) [36] foundin Sefrou at the Sidi Bouali source lower values that were varied between $17^{\circ} \mathrm{C}$ and $18^{\circ} \mathrm{C}$.

The Cond designs the mineralization level of water to indicate the ionic concentration and appreciates the amount of salts dissolved in the water. The electrical conductivity measured for the nine samples shows values ranged from 820 and $3250 \mu \mathrm{S} / \mathrm{cm}$, as shown in Figure 3.

The electrical conductivity exhibited high P6 and P8 wells values, with amaximum value recorded in the well $8(3250 \mu \mathrm{S} / \mathrm{cm})$. According to the Moroccan water standards, $22 \%$ of ourwater samples collected from the study area wells are very strongly saline as the values found for Cond $(<2700 \mu \mathrm{S} / \mathrm{cm})$ classify the waters of the Jouamaa Hakama siteas poor quality while the other wells are classified as moderate quality according to this characteristic. These higher values of electrical conductivity can be related to the human activities pressures on these aquifers, including agriculture and the use of fertilizer and pesticides, which can contribute to the increase of water salinity. It was reported in Davidson and Wilson 2011 that when the EC is higher in shallower wells, this is mainly due to a combination of land use increase and aquifer processes, while in 
deeper wells, the higher Cond values reflect a natural process of aquifer reaction. This result appears to be comparable to that reported by Belghiti in the Meknes well water (2013) [25], while Bouderka found values ranging between 770 and 9890 in the groundwater of Lgharb (Morocco) [26].

Table 2: Results of $\mathrm{pH}, \mathrm{T}^{\circ}$, DCO, DBO5, and SM.

\begin{tabular}{|c|c|c|c|c|c|c|c|c|c|c|}
\hline & & P9 & P 8 & P7 & P6 & P 5 & P 4 & P 3 & P 2 & P 1 \\
\hline & $\begin{array}{c}\text { Depth } \\
(\mathrm{m})\end{array}$ & 5 & 4,70 & 5 & 5 & 5 & 3 & 6 & 6 & 4,30 \\
\hline \multirow{2}{*}{ 펼 } & 2016 & 7,63 & 7,47 & 7,86 & 7,43 & 7,88 & 7,17 & 7,67 & 7,27 & 8,05 \\
\hline & 2017 & 6,82 & 7,04 & 7,19 & 7,67 & 7,82 & 6,92 & 6,93 & 7,42 & 7,15 \\
\hline \multirow{2}{*}{$\therefore \mathcal{O}$} & 2016 & 19,8 & 18,8 & 20,4 & 20,3 & 20,7 & 20,9 & 20,8 & 20,7 & 20,9 \\
\hline & 2017 & 20,6 & 19,9 & 20 & 20,4 & 20,5 & 20,7 & 20,5 & 20,2 & 20,3 \\
\hline \multirow{2}{*}{ ¿ } & 2016 & 1,05 & 32 & 8,54 & 18,7 & 4 & 3,76 & 5,20 & 15,3 & 9,88 \\
\hline & 2017 & 22,6 & 24,6 & 17,9 & 20,1 & 25,5 & 18,7 & 27,7 & 35,2 & 42,9 \\
\hline \multirow{2}{*}{ 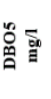 } & 2016 & 0 & 29 & 8 & 7 & 2 & 3 & 4 & 10 & 5 \\
\hline & 2017 & 10 & 9 & 10 & 8 & 15 & 7 & 15 & 20 & 18 \\
\hline \multirow{2}{*}{ 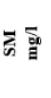 } & 2016 & 0 & 13 & 4 & 3 & 2 & 17 & 22 & 8 & 4 \\
\hline & 2017 & 5 & 6 & 5 & 4 & 12 & 3 & 9 & 13 & 13 \\
\hline
\end{tabular}

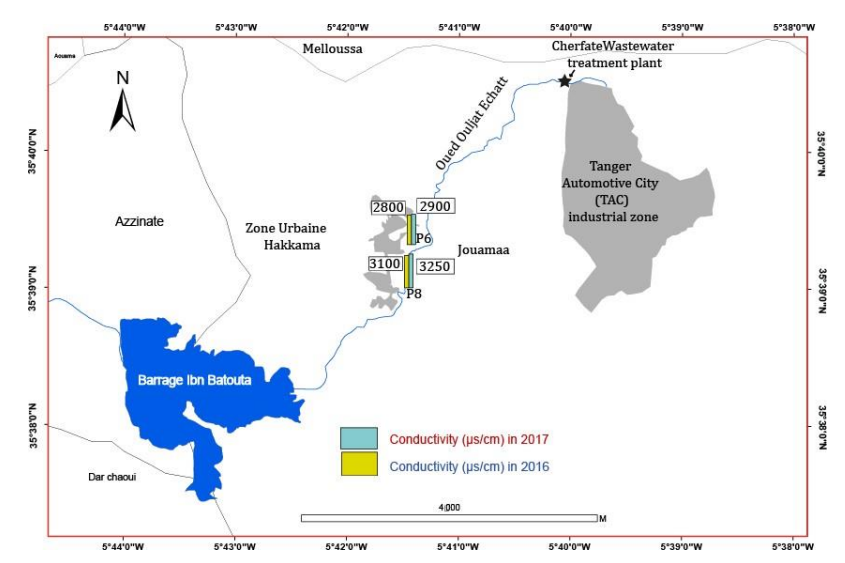

Fig.3. The electrical conductivity values measured in the water samples

\subsubsection{Turbidity, dissolved oxygen and SM}

The turbidity measured in water samples retrieved from the studied wells varies from one well to another. The values range from 1.25 to 20.1 FNU (Figure 4), exceeding the regulation limit (1,5 FNU), which seems linked to heavy rainfall, direct discharges, or disturbance of the river bed.

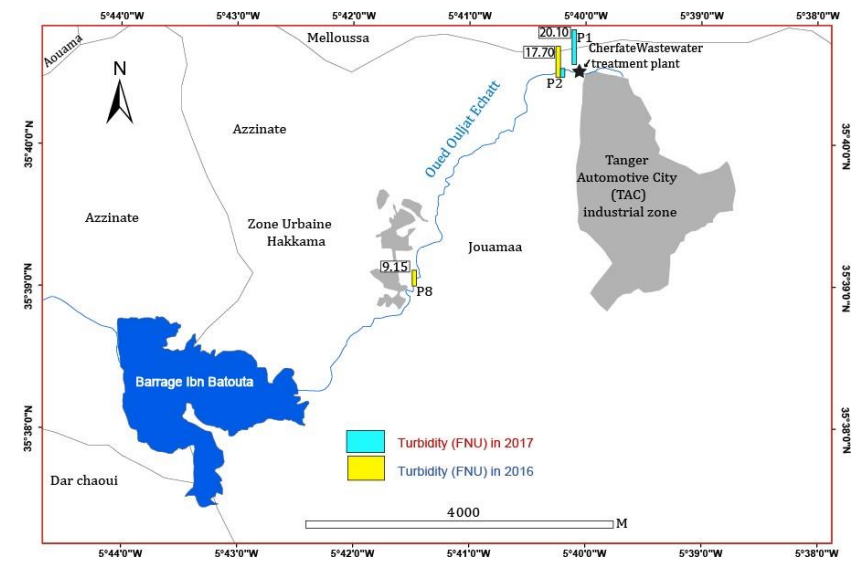

Fig.4. Turbidity values measured for water samples.

In groundwater, dissolved oxygen levels are relatively lower because of the weak contact with the atmosphere and lack of water turbulence [29]. The lowest concentrations are recorded for P6 $(3.2 \mathrm{mg} / 1$ in winter 2016 and $2.82 \mathrm{mg} / \mathrm{l}$ in summer 2017), P8 (2.08 mg/l in winter 2016 and $1.59 \mathrm{mg} / \mathrm{l}$ in summer 2017) and P9 $(4.84 \mathrm{mg} / \mathrm{l}$ in winter 2016 and $3.22 \mathrm{mg} / 1$ in summer 2017). On the contrary, the $\mathrm{P} 3, \mathrm{P} 4, \mathrm{P} 5$ and $\mathrm{P} 7$ wells are more or less well-oxygenated and meet the quality standards for water intended for human consumption 5 $<\mathrm{O} 2<8$. The results found by Er-Raioui in 2011 in the province of Larache [30] have exhibited high dissolved oxygen values that vary from 6 to $9.3 \mathrm{mg} / \mathrm{l}$. While Laghzal, 2014 study carried out in the Tangier region [31] showed lower concentrations, which meet the quality standards of water intended for human consumption.

In the study site, there are significant variations between the different sampling stations. The value of the Suspended Matter (SM) contents (Table) shows a peak at $\mathrm{P} 2$, which reaches $130 \mathrm{mg} / \mathrm{l}$ (well P2), but which remains below the value admissible by Moroccan standards [42]. 


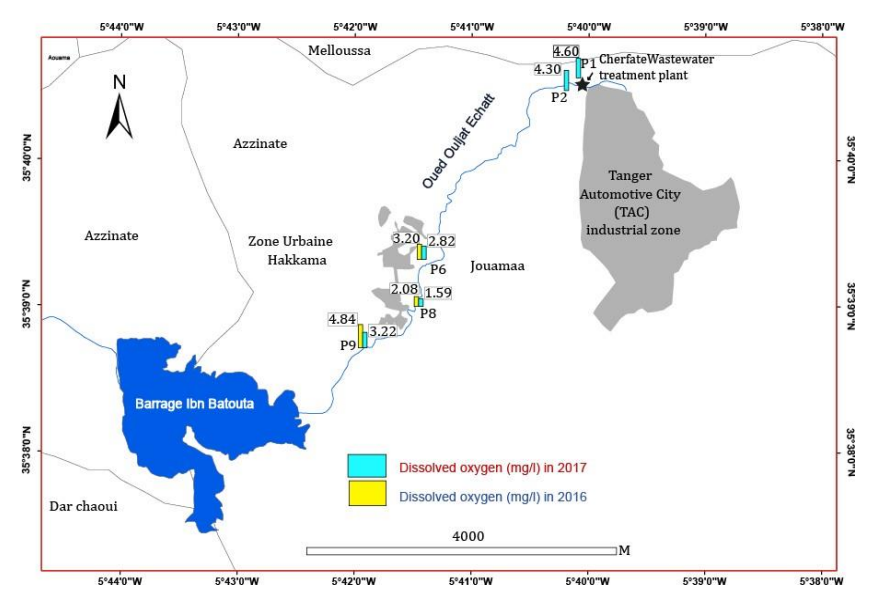

Fig.5. Dissolved oxygen concentration measured in the water samples

\subsection{Chemical parameters}

\subsubsection{COD and BOD5}

The Chemical Oxygen Demand (COD) represents the quantity of oxygen, in $\mathrm{mg} / \mathrm{l}$, necessary for the chemical degradation of all organic matter, biodegradable or not, contained in water. The highest values for this parameter are recorded near the WWTP at well P9 in August (42.90 mg of O2 / 1). COD values for all wells water studied in winter and summer do not exceed the values set by Moroccan standards and by WHO. In contrast, E.M. Hassoune et al. (2006) [37] found in Settat that the average COD values for all the water in the studied wells exceeded $80 \mathrm{mg} / \mathrm{l}$. While El haissoufi et al., $2011 \mathrm{in} \mathrm{Fez}$ [39] found non-conforming values of COD varying from $24.53 \mathrm{mg} / 1$ to $263.3 \mathrm{mg} / \mathrm{l}$

The BOD5 (Biochemical Oxygen Demand) allows the evaluation of biodegradable organic matter present in water. The increase in BOD values could be explained by organic pollution from anthropogenic activities. The obtained results indicate that the majority of wells have BOD5 contents that exceed the drinking water threshold of $10 \mathrm{mg} / \mathrm{l}$ for category A3 [42];

\subsubsection{Ammonium (NH4+)}

The ammonium is present in the prospected wells, with content varying between $0.331 \mathrm{mg} / \mathrm{L}$ and $0.569 \mathrm{mg} / \mathrm{l}$ (Fig. 6). The values of some wells are slightly higher than the Moroccan standards values. In general, the obtained values are inferior and close to the value of the standards for drinking water/human consumption (0.5 $\mathrm{mg} / \mathrm{l}$ ) as they do not exceed $0,57 \mathrm{mg} / \mathrm{l}$ recorded in $\mathrm{P} 4$. Our finding is in good accord with the results found in the Tangier-Tetouan region through analyzing water springs (Laghzal et al., 2014).

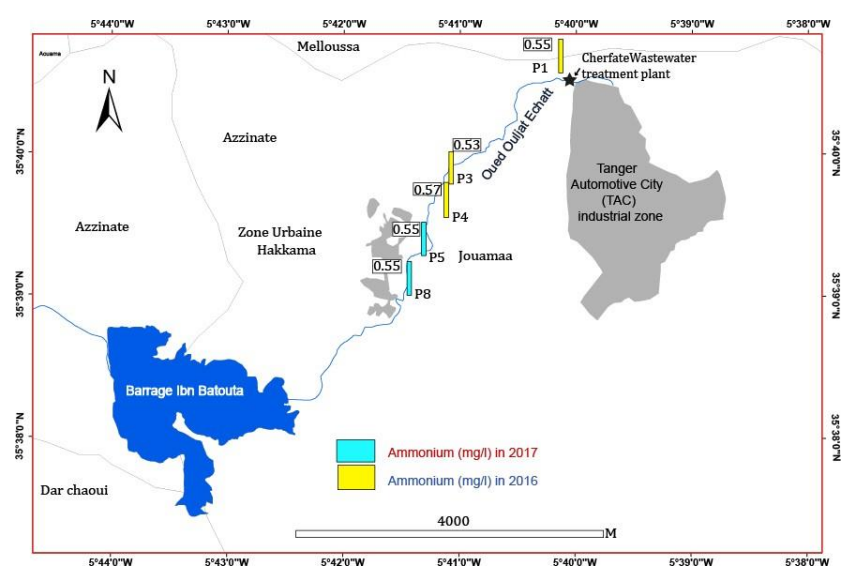

Fig.6. Ammonium concentrations measured in water samples.

\subsubsection{Nitrites and Nitrates}

Nitrites and nitrates are naturally occurring ions in the environment. They are the result of the nitrification of the ammonium ion $\left(\mathrm{NH}_{4}{ }^{+}\right)$. They are extremely soluble; they penetrate the soil and underground water, flowing into streams by runoff. They are one of the major causes of long-term water degradation. The degradation of nitrogenous matter forms nitrites, but they are quickly transformed into nitrates in drinking water sources. According to European standards [33], water intended for human consumption must not contain nitrites at levels greater than $0.5 \mathrm{mg} / \mathrm{l}$. The results of the nitrites' analyses show that their contents oscillate between $0.126 \mathrm{mg} / \mathrm{l}$ and $2.26 \mathrm{mg} / \mathrm{l}$. (figure 7). Belghiti et al. (2014) [34] found lower concentrations of nitrites in the Meknes region, where the highest value was $0.09 \mathrm{mg} / \mathrm{l}$, and the minimum value is approximately $0.011 \mathrm{mg} / \mathrm{l}$ recorded in the community of Bouderbala. In contrast, the values found in the groundwater of Martil by Lamribah et al. (2013) [35] were ranged between 0.001 $\mathrm{mg}$ and $4.574 \mathrm{mg} / \mathrm{L}$. 


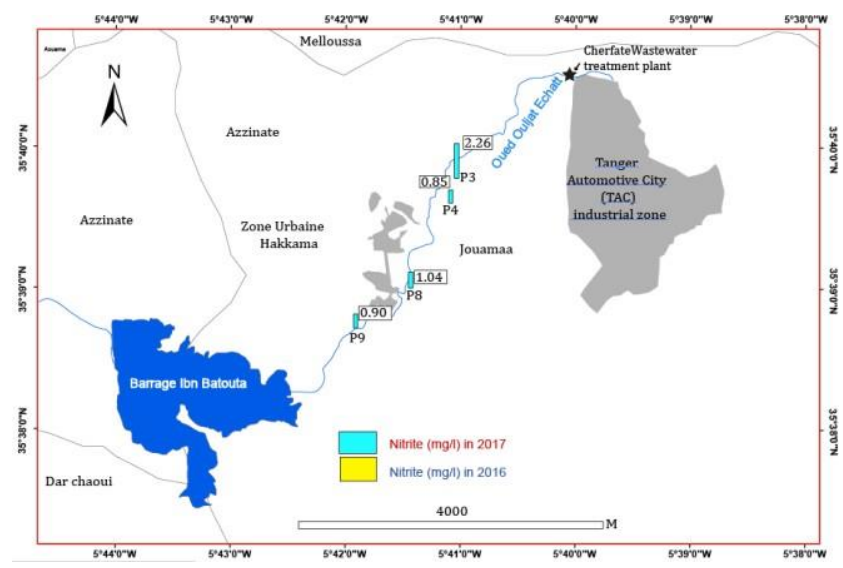

Fig.7. The concentrations of Nitrite measured in water samples.

\subsubsection{Phosphates}

Orthophosphates most often have an urban origin (components of detergents) or agricultural (leaching of fertilizers). It is generally known that variations in phosphate concentrations constitute the limiting element of eutrophication phenomena [29]. If they exceed the standards, these are regarded as an indication of faecal contamination leading to a proliferation of germs, taste and colouring [28]. Indeed, this parameter is generally subject to special monitoring. A high phosphate content can indicate agricultural pollution following the leaching of fertilizers and depends mainly on the geological nature of the substratum [36]. Phosphate concentrations are higher during the dry period in most of the wells in the study area, and seven out of nine wells have high phosphate concentrations. The values of this parameter in the studied waters are very variable and range from $0.408 \mathrm{mg} / \mathrm{l}$ to $3.48 \mathrm{mg} / \mathrm{l}$.

These values in the wet period oscillate between 0.198 $\mathrm{mg} / \mathrm{l}$ and $0.991 \mathrm{mg} / \mathrm{l}$. (figure 8). These values are similar to those reported in previous studies done in the Settat region [37]. In contrast, Otchoumou et al. (2017) [38], in their research in Binger Ville's groundwater in the Ivory Coast, exhibited standards values ranging from $0.004 \mathrm{mg} / \mathrm{l}$ to $0.29 \mathrm{mg} / \mathrm{l}$.

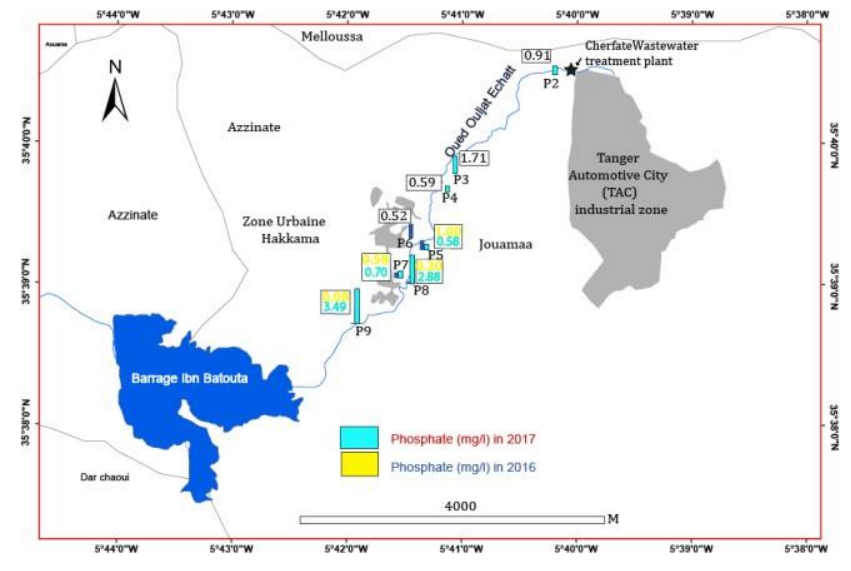

Fig.8. Phosphate concentrations measured for each sample.

\section{CONCLUSION AND PERSPECTIVES}

Groundwater contamination is a primary concern for stakeholders, decision-makers and managers of water resources.

The present study carried out on nine wells situated at the Jouamaa Hakama site to evaluate their water quality by determining the Cond, $\mathrm{T}^{\circ}$, DO, Turbidity, COD, $\mathrm{DBO}_{5}$, phosphate, Nitrite, Nitrate and Ammonium. Almost all the higher concentrations were recorded in the sampling locations situated in urban zone Hakama, which lets us conclude that water contamination in this area is mainly due to urban activities and agriculture activities.

GIS tool can help decision-makers for preserving and protecting groundwater in planning and managing these natural resources.

This work has shown result remains worrying in human and animal health. To improve the Jouamaa Site wells water quality, it is recommended to program additional field studies and analysis such as bacteriological and heavy metals analysis, and more depth on the Charafate wastewater treatment plant effectiveness and the Tangier Automotive City industrial zones in order to see the conformity industrial status. More studies must be done on the techniques and methods of installing suitable treatment for liquid effluents from agriculture, industrial and urban areas in the region and establishing deep monitoring of the domestic water sanitation network for the urban riparian areas to maintain its balance.

\section{ACKNOWLEDGMENT}

The authors would like to thank all the collaborators within this work, from the Field sampling, laboratory 
analysis and writing manuscript team. El Khalil Cherif supported by FCT with the LARSyS - FCT Project UIDB/50009/2020 and by FCT project VOAMAIS (PTDC/EEI-AUT/31172/2017, 02/SAICT/2017/31172)

\section{REFERENCES}

[1] Smith M, Cross K, Paden M, Laban, P Spring, 2016 Managing Groundwater Sustainability; IUCN: Gland, Switzerland, 2016; Volume 11.

[2] El Omran E, Ghallab A, Selmy S, Gad A (2014) Evaluation and mapping water wells suitability for irrigation using GIS in Darb El-Arbaein, South Western Desert, Egypt. IJWRAE 3(1):63-76.

[3] Asfers Y, Taouil H, Amine A, Doubi M, Ibn Ahmed S 2017. Assessment of metal pollution in the waters of the Oulja wells, OumEr-Rbia watershed, Chem., Res. J., 2(5):186-191.

[4] Marsala R.Z, Capri E, Russo E, Barazzoni L, Peroncini E, De Crema M, Labarta R.C, Otero N, Colla R, Calliera M, Fontanella M. Ch, Suciu N.A, 2020. Influence of nitrogen-based fertilization on nitrates occurrence in groundwater of hilly vineyards. Science of The Total Environment, 766, 2021, 144512,

https://doi.org/10.1016/j.scitotenv.2020.144512.

[5] Marić N, Štrbački J, Mrazovac Kurilić S, et al. 2020. Hydrochemistry of groundwater contaminated by petroleum hydrocarbons: the impact of biodegradation (Vitanovac, Serbia). Environ Geochem Health 42, 19211935 (2020). https://doi.org/10.1007/s10653-019-00462-9.

[6] Rahman, M.A.T.M.T., Paul, M., Bhoumik, N. et al. Heavy metal pollution assessment in the groundwater of the Meghna Ghat industrial area, Bangladesh, by using water pollution indices approach. Appl Water Sci 10, 186 (2020). https://doi.org/10.1007/s13201-020-01266-4.

[7] Nazina T, Babich T, Kostryukova N, Sokolova D, Abdullin R, Tourova T, Kadnikov V, Mardanov A, Ravin N, Grouzdev D, Poltaraus A, Kalmykov S, Safonov A, Zakharova E, Novikov A, Kato K 2020. Ultramicrobacteria from Nitrate- and Radionuclide-Contaminated Groundwater. Sustainability. 2020; 12(3):1239. https://doi.org/10.3390/su12031239.

[8] Pandey PK, Kass PH, Soupir ML, Biswas S, Singh VP. 2014. Contamination of water resources by pathogenic bacteria. AMB Express. 2014 Jun 28;4:51. doi: 10.1186/s13568-014-0051-x. PMID: 25006540; PMCID: PMC4077002.

[9] EPA. United States Environmental Protection Agency. Available at https://www.epa.gov/privatewells/potential-well-water-contaminants-andtheir-impacts; (Accessed in 15 April 2021).

[10] Eberts S. M, 2014. If groundwater is contaminated, will water from the well be contaminated?. Ground water, 52 Suppl 1 (Suppl 1), 3-7. https://doi.org/10.1111/gwat.12260.

[11] Muralikrishna I.V, Manickam V, 2017. Solid waste management. In: Muralikrishna I.V., Manickam V. (eds) Environmental Management Science and Engineering for Industry. Butterworth-Heinemann, pp. 431462

[12] Malki M, Choukr-Allah R, Bouchaou L, Hirich A, Ait Brahim Y, Krimissa S, Hssaisoune M, Nghira A, Barceló D, 2017. Assessment of Groundwater Quality: Impact of Natural and Anthropogenic Contamination in SoussMassa River Basin. In The Souss-Massa River Basin, Morocco; Springer: Cham, Switzerland, 2017; Volume 53.

[13] Hssaisoune M, Bouchaou L, Sifeddine A, Bouimetarhan I, Chehbouni A. 2020. Moroccan Groundwater Resources and Evolution with Global $\begin{array}{llll}\text { Climate } & \text { Changes. } & \text { Geosciences. 2020; } & \text { 10 }\end{array}$ https://doi.org/10.3390/geosciences 10020081.

[14] Chenaker H, Ibrahimia R, Mejjad N, Hamad S. M., 2020. Youth in Action on Policy Implications of Climate Change Impacts on Water Resources in North Africa: Algeria, Tunisia, Morocco and Libya. in (Extended Abstract volume), UNESCO Special Publication on Youth and Water Security. DOI: 10.13140/RG.2.2.11670.47686

[15] Douhri H, Raissouni I, Douhri B, Zaoujal A, Benchakhtir M, Tazi S, Bouchta D, and Chaoukat F, 2015. The quality of groundwater in several sites of Tangier Tetuan Region (Morocco), International Journal of Innovation and Scientific Research, Vol. 13 No. 1 Jan .2015, pp. 257-263.

[16] Azzirgue E-M, and Salmoun F, 2019. Assessment of the Physico-Chemical Quality of Water of Oued Ouljat Echatt and Dam Ibn Batouta-Tangier. International Journal of Advances in Scientific Research and Engineering (ijasre). E-ISSN: 2454-8006. Volume 5, Issue 10 October - 2019.

[17] Michard A, (1976). Eléments de géologie marocaine. Editions du service géologique marocain, Rabat, 41p, 1976.

[18] Yassir T. et al, (2016). Etude Hydrogéologique préliminaire de la zone des flysch à l'Ouest de Tétouan (Maroc). International Journal of Innovation and Applied Studies. ISSN 2028-9324 Vol. 14 No. 3 Feb. 2016, pp. 653667

[19] El Gharbaoui A, (1981). La terre et l'homme dans la péninsule tangitaine. Etude sur l'homme et le milieu dans le Rif occidental, Edi. Institut scientifique de Rabat, Service géologique et géographique, Rabat, Maroc, 439 p, 1981.

[20] KARROUK M.S. (1990). Aperçu sur les mécanismes climatiques rifains. Le Rif, l'espace et l'homme. Rev. Fac. Lettres, Tétouan, 4, 11-36

[21] ACHAB M. (2011). Les plages et les vasières des environs des embouchures des oueds Tahaddart et Gharifa (NW du Maroc): dynamique morphosédimentaire et impact des aménagements sur leur évolution récente. Dans: Proceedings of the Fifth International Symposium on Sandy
Beaches, Sandy Beaches and Coastal Zone Management, 19-23 octobre 2009, Rabat, Morocco. Travaux de l'Institut Scientifique, Rabat, série générale, $2011, \mathrm{n}^{\circ} 6,1-12$

[22] Nabil RIFA et al, (2013). Modélisation des crues des rivières pour la gestion intégrée du risque d'inondation : cas du bassin versant de Tahaddart (NordOuest du Maroc). Revue des Sciences de l'Eau 27(1) (2014) 57-69. ISSN 1718-8598

[23] Mahamat S. et al 2015. Évaluation de la qualité physico-chimique des eaux d'adduction publique de la Société Tchadienne des Eaux à N'Djamena au Tchad. J. Appl. Biosci.

[24] Alemad et al. (2016). Note sur les causes de la dégradation de qualité des eaux souterraines de l'aquifère de sana' a -Yémen- Note about the causes of the deterioration of groundwater quality in aquifer of Sanaa -Yemen-J. Mater. Environ. Sci. 7 (1) (2016) 161-169. ISSN : 2028-2508

[25] Belghiti M.L. 2013. Etude De La Qualité Physico -Chimique Et Bactériologique Des Eaux Souterraines De La Nappe Plio-Quaternaire Dans La Région De Meknès (MAROC). Larhyss Journal, ISSN 1112-3680, $n^{\circ} 14$, Juin 2013, pp. 21-36

[26] Bouderka N et al. 2016. Evaluation De L'impact De La Pollution Agricole Sur La Qualité Des Eaux Souterraines De La Nappe Du Gharb. (MAROC). Larhyss Journal, ISSN 1112-3680, $n^{\circ} 14$, Juin 2013, pp. 21-36. European Scientific Journal April 2016 edition vol.12, No.11 ISSN: 1857 - 7881 (Print) e - ISSN 1857- 7431509

[27] Ghazali, D. \& Zaid, A. 2013. Etude de la qualité physico-chimique et bactériologique des eaux de la source Ain Salama-Jerri (région de Meknès, Maroc). Larhyss Journal, (12) : 25-36.

[28] Rodier (J.) (2009) - L'analyse de l'eau : eaux naturelles, eaux résiduaires, eau de mer : chimie, physico-chimie, microbiologie, biologie, interprétation des résultats, 9éme édition, Dunod, Paris, 1 (1959), 2009

[29] AÏT BOUGHROUS A. (2007). Biodiversity, ecology and groundwater quality two arid regions of Morocco, thesis for the Degree of Doctor, University Cadi Ayad, Morocco.

[30] A. Laghzal et F. Salmoun / Larhyss Journal, 20 (2014), 7-24. Contribution to the characterization of the physico chemical quality of water of some springs in the region of Tangier-Tetouan (Morocco)

[31] H. ER-RAIOUI et al. / Int. J. Biol. Chem. Sci. 5(3): 1118-1134, 2011. Contamination des eaux souterraines par le lixiviat des décharges publiques : Cas de la nappe phréatique R'Mel (Province de Larache - Maroc NordOccidental)

[32] Maoudombaye T. \& al. (2015), Etude comparative de la qualité physicochimique des eaux de puits, de forages et de rivières consommées dans le bassin pétrolier de Doba au Tchad. Larhyss Journal, ISSN 1112-3680, n² 24 , Décembre 2015, pp. 193-208

[33] Normes Européennes. (1998). Directives du conseil 98/83/EC sur la qualité de l'eau

[34] L. Belghiti et al. (2014), Effect of anthropic activities on the quality of subsoil waters in rural medium in the area of Meknes (Morocco). Larhyss Journal, ISSN 1112-3680, n 17 , Mars 2014, pp. 77-89

[35] Lamribah A. et al. (2013). Impact de la pollution urbaine sur la contamination par les nitrates et les nitrites de la nappe phréatique de Martil (Maroc). Larhyss Journal, ISSN 1112-3680, n¹4, Juin 2013, pp. 79-91

[36] I. Nechad et al. (2014). Qualité physicochimique des eaux des sources Ain Regrag et Ain sidi Bouali dans la région de Sefrou (moyen atlas, Maroc). Larhyss Journal, ISSN 1112-3680, n²0, Décembre 2014, pp. 127-146

[37] E.M. Hassoune et al. (2006). Effets des rejets liquides domestiques et industriels sur la qualité des eaux souterraines au nord de la ville de Settat (Maroc). Bulletin de l'Institut Scientifique, Rabat, section Sciences de la Vie, 2006, n²8, 61-71.

[38] F. Kanohin Epse Otchoumou et al. (2017) Caractérisation physico-chimique et bactériologique des eaux souterraines de Bingerville/ Int. J. Biol. Chem. Sci. 11(5): 2495-2509, 2017

[39]El haissoufi H., et al. (2011). Pollution des eaux de puits de certains quartiers de la ville de Fès, Maroc, Rev. Microbiol. Ind. San et Environn. Vol 5, $\mathrm{N}^{\circ} 1, \mathrm{p}: 37-68$

[40] M. Ben Abbou et al. (2013), Détermination de la qualité des eaux souterraines des nappes de la province de Taza (Maroc). Larhyss Journal, ISSN 1112-3680, $\mathrm{n}^{\circ} 16$, Décembre 2013, pp. 77-90

[41] N. Brinis et al. (2015), analyse statistique et géochimique de la dynamique des paramètres physico-chimiques des eaux souterraines du synclinal de Ghassira Algérie orientale. Larhyss Journal, ISSN 1112-3680, n²2, June 2015, pp. 123-137

[42] NM03.7.001, $2006:$ : Norme marocaine relative à la qualité des eaux d'alimentation humaine. Bulletin Officiel N 5404 du 16 Mars 2006. 